\title{
An Assessment of Loans and Advances, Business Advisory Services, and Their Effects on Rural Development Among Rural Banks in Wenchi Municipality
}

\author{
Luther Ntim Adjei* Gifty Asieduwaa Adoma \\ School of Business, Valley View University P.O.Box 183, TMA. Techiman, BE/R, Ghana
}

\begin{abstract}
Ghana, like other Sub-Saharan African countries, has generally experienced low productivity, low-income levels, low local reserve funds, and unemployment. The entire rural population of Ghana is about 45.32 percent of the total population of Ghana. However, due to inadequate credit supply and lack of business consulting services, rural people face problems. Initially, sources of rural credit include institutional and non-institutional. The noninstitutional credit is provided by money lenders, relatives, friends, traders, commission agents, and cooperatives, which attract very high-interest rates. This, therefore, brought about the idea of the rural bank in 1976 with the aim of channeling financial credit to rural dwellers for the promotion of local ventures and accelerated development in these areas in order to raise the standard of living of rural dwellers. This present study assessed the relationship between loans and advances and business advisory services of rural banks towards rural development in the Wenchi municipality. The descriptive research design was employed and questionnaires.was used for collecting data from respondents. The study used stratified random sampling and accidental/convenience sampling to select a sample size of 609 , comprising of 9 staff and 600 customers of the banks. The study revealed that there was a strong but inverse relationship between loans and advances that were given to customers and the performance of the rural banks in rural development. The study also found out that there was a positive correlation between the status of business advisory services in rural banks and rural development. With respect to the challenges the rural banks face in granting loans and advances, it was revealed that high-interest rate, high default rate, and lack of collateral security were major challenges encountered by the banks in providing loans and advances to rural dwellers to improve on rural development. The study recommended that rural banks should place much emphasis on developing the facility of business advisory services to assist and support rural dwellers on how to manage their finances properly in order to translate into developing rural areas.
\end{abstract}

Keywords: Loans and Advances, Business Advisory Services, Rural Development.

DOI: $10.7176 /$ RJFA/11-12-12

Publication date:June 30th 2020

\section{Introduction}

Banking is essentially the financial transactions that are carried out by firms under the auspices of the government or a government institution. Generally, banking involves the activities that safeguard or transfer funds, facilitate the issuing of loans, guaranteeing credit-worthiness, and exchange of money. The role of rural banks ensures that these banking services are rendered to people in the rural fields that do not have easy access to corporate and commercial banks. The purpose for the creation of rural banks ensures that their activities are linked with the development of the rural areas (Alhassan, 2018). In that regard, rural development forms the core vision of any rural bank, particularly in Ghana. This study gravitates towards the activities of rural banks and their relationship with rural development.

\subsection{Background to the Study}

Banks play a significant role in resource mobilization and distribution in any country. Rural people face insufficient loan provisioning issues. The principal credit source for rural households, particularly low-income working households, have been the informal sector. The informal sector is advancing loans at very high-interest rates; the terms and conditions of those loans have contributed to an elaborate oppressive system of both economic and noneconomic conditions in rural residents. Ghana, like other Sub-Saharan African countries, has generally experienced low productivity, low-income levels, low local reserve funds, and unemployment. The idea of rural bank evolved in Ghana in 1976 when the government of Ghana, through the Bank of Ghana (BOG) established rural banks with the aim of channeling financial credit to rural dwellers for the promotion of local ventures and accelerated development in these areas, and raise the standard of living of rural dwellers (Owusu-Antwi, 2009). Right from the 2010s, the largest providers of financial services to rural areas are rural banks and hold a significant number of the total banking outlets in the country (Afful, Hejkrlik, \& Doucha, 2015).

The fundamental feature of economic development is the focus on socio-economic and human capital development within the rural sectors (Platteau, 2015). The sustainable way of promoting the economy of rural areas enhances the employment opportunities in these rural areas and reduces the regional income disparities and 
reduces the rate of rural-urban migration. Furthermore, developing rural areas ensures the protection of the rural landscape and ensures the indigenous cultures and traditions through the promotion of rural programs. The entire rural population of Ghana is about 45.32 percent of the total population of Ghana (Ghana Statistical Service, 2016). It means that there has to be more development in rural areas to effect overall development in the country.

The objective of establishing rural banking was to provide institutional credit to rural dwellers, which is used to support rural enterprises and businesses, which consequently leads to rural development. In that regard, rural credit helps the poor to start-up enterprises and expand the existing businesses. An additional goal was to ensure rural dwellers had access to financial knowledge about agricultural as well as rural enterprises by rendering business advisory services. Muller (2012) asserts that business advisory services (BAS) are essentially consulting services that are focused on promoting business enterprises.

Originally, sources of rural credit include institutional and non-institutional. Non-institutional credit is provided by money lenders, relatives, friends, traders, commission agents, and cooperatives. There is relatively no interest or collateral for loans provided by friends and family. However, credit provided by money lenders and traders attracts very high-interest rates (Afful, Hejkrlik, \& Doucha, 2015). Rural dwellers make long travels to access financial services (such as salary and pension pay), make cash payments for their agricultural produce, or have access to certain business advisory services for their rural/agricultural enterprises (Nair \& Fissha, 2010). This was due to the lack or absence of savings and payment facilities in rural communities. It is recognized that for economic development to be accelerated, there is a need for larger institutional sources of credit to be created.

The fundamental goal for the establishment of rural banks was to make financial credit available to rural dwellers to facilitate growth and development in rural areas. As of August 2018, there were about 144 rural and community banks (RCBs) with over 600 branches/agencies in the country (Bank of Ghana Banking Sector Report, 2018).

Afriyie and Akotey (2013) pointed out that the entire group of rural and community banks constitute the largest banking network in Ghana with the aim of helping improve the standard of living of the rural poor, which would lead to rural development in Ghana. The rural banks are created with the purpose of ensuring small scale enterprises, as well as small towns, benefit from the new credit source. To ensure that rural banks translate increased credit and savings opportunities in economic growth, this study seeks to assess the role of rural banks on economic development in Ghana through loans and advances and business advisory service (BAS) provided to the rural communities.

\subsection{Statement of the Problem}

Internationally, poverty remains a rural phenomenon (Rodrik, 2016). Most rural dwellers have a very low standard of living. Enterprise activity in rural areas is relatively low, and access to a formal source of finance for any kind of enterprise or business activity is almost nonexistent. Before the establishment of rural banks, the main source of credit for rural folks was private money lenders who charged high fees for monies granted (Afful, Hejkrilik, \& Doucha, 2015).

In Ghana, the section of the population who are economically active are provided with financial services by the formal financial institutions while the rest of the population are excluded from access to formal financial services. This section of the population that is excluded from the formal financial services is served by informal institutions such as the non-governmental organization (NGOs) - microfinance, moneylenders, friends, relatives, and credit unions (Rodrik, 2016).

Carley and Christie (2017), in their study, also confirmed the assertion that rural people are poor and promoting economic development in rural areas is directed towards lifting the standard of living of the poor and ensuring favorable changes in the way of life of the people concerned. As a result, in 1976, the Government of Ghana under the auspices of the Bank of Ghana (BoG) established rural banks to direct credit to rural areas, which would promote rural ventures and bring about sustainable rural development (Quartey, Danquah, \& Iddrisu, 2017).

The poor rural development, according to Afful et al. (2015), is as a result of lack of accessibility to credit facility due to high-interest rate, high default rate, the inability of rural dwellers to offer adequate security for loans and lack of business advisory services.

The idea of rural development has promoted the establishment of many rural banks in the country. Most of these rural banks demonstrate that their products and services are benefiting rural dwellers. And some of these products that rural and community banks assert to deliver include readily available loans and advances to rural dwellers, while some services include business advisory services. However, the provision of business advisory services is not the primary objective of rural banks in the country. Also, adequate measures are not put in place to provide these advisory services to rural dwellers (Osei, 2016). In view of this, the present study sought to answer the following questions:

1. Is there a significant relationship between loans and advances of rural banks and rural development?

2. Is there a significant relationship between business advisory services of rural banks and rural development?

3. What are the challenges faced by rural banks in developing rural communities in the Wenchi Municipality? 


\subsection{Purpose of the Study}

The study specifically sought:

1. To determine if there is a significant relationship between loans and advances and rural development in the Wenchi Municipality.

2. To decide if there is a significant association between business advisory services and rural development in the Wenchi municipality.

3. To examine the challenges faced by rural banks in developing rural communities in the Wenchi Municipality.

\subsection{Significance of the Study}

This research is of enormous significance to its stakeholders, namely; rural banks, national board for small scale (NBSSL), academia, rural communities and, the government. The subject area outlines both the challenges and the potential for rural banks to go and stimulate capital provisions to rural folks, especially the enterprising poor in a financially, economically, and socially sustainable manner. This work develops interventions to close the gap in financing enterprises of rural folks by outlining the leading roles of rural banks towards economic development. The study outlines key financial instruments that easily benefit enterprises of rural folks in their development. The study also outlines key reasons why some enterprises of rural folks fail in their hunt to access finance. This will guide all enterprises of rural folks to make sure that they adopt the right procedures in accessing financial support. The study would also make valuable contributions to the wider debate of rural banking schemes and economic development both in academia and in the business world. Finally, this study would motivate and guide others to conduct further research in this field of study.

\subsection{Scope and Limitations of the Study}

Geographically, the scope of the study covered all the rural banks in the Wenchi municipality of the Bono region of Ghana. Out of the 144 registered rural banks in Ghana currently, there are three of these rural banks in the Wenchi municipality (Bank of Ghana Banking Sector report, 2018)

The issue of rural banking is entirely a broad issue altogether, and hardly can one explore every aspect of it. Contextually, the study found the effect of rural banks on economic development in Ghana. The study focused on modalities and enterprises of rural folks in accessing micro-credit, the role of the selected rural banks to economic empowerment in the municipality, and the extent of the veracity of the rural bank's operations towards economic development in their operational areas.

The limitation that was encountered by the researcher in the field was the language barrier. This is where some customers of the bank being illiterates, it became difficult administering questionnaire that has been designed in English. This means that the questionnaire had to be translated into the local language to the respondents.

\section{Literature Review}

\subsection{Conceptual Framework}

The conceptual framework reviewed various literature under the following headings. The Conceptual framework discussed the various components of rural banks and how rural banks contribute to rural development. The conceptual framework presented a review in six sections.

\subsubsection{Evolution of Rural and Community Banks}

In 1976, before the establishment of the first rural bank in Ghana, there was limited access to loan facilities in rural communities, which is mostly made up of fishermen and farmers (Dzadze, Aidoo \& Nurah, 2012). The primary source of funds to these rural dwellers was cash creditors and traders who offered a high interest in access to these funds (Dzadze et al., 2012). In that regard, the government of Ghana enacted policies that helped facilitate rural dwellers' access to finance. One such initiative was the formation of the agriculture development bank in 1965 with the primary purpose of providing the needed credit for agricultural ventures. The Ghanaian government also ensured banks maintained 20 percent of their portfolio for agricultural ventures.

Over time, several branches of the agricultural development bank, as well as commercial banks, were opened in rural areas (Bawumia, 2015). However, lending to the rural sector remained relatively low as compared to urban areas. This is as a result of certain demands of commercial banks such as stronger collateral requirement. Nair and Fissha (2010) pointed out that rural dwellers such as farmers and fishermen do not regularly keep deposits accounts with commercial banks, and as such, they are unable to provide the needed collateral when seeking out loans or advance. In that regard, the government of Ghana established rural banking in rural areas to cater to the needs of providing financial credit and services to these rural dwellers (Nair \& Fissha, 2010).

\subsubsection{Functions of Rural Banks}

In Ghana, rural banks were established to direct credit for productive ventures in rural areas for rural development (Agyapong, 2016). Rural banks, like any other established institution, would automatically perform so many functions in addition to the rationale for their establishment or their core functions. The most populous type of 
financial institutions in rural communities is rural banks and credit unions (Flora, 2018). The role these institutions in rural areas play helps promote the rural economy by providing rural dwellers certain basic financial services. For example, rural banks help farmers by providing the needed funds to buy seedlings and market their produce.

The differences in rural banks are determined by their ownership. Rural banks are primarily owned by private individuals and managed by individuals in communities in which the bank operates (Birchall, 2012). AsieduMante (2011) pointed out that rural banking attempts to offer all the basic banking services that people living in rural areas need. Cash deposits are the most common financial transaction operated in rural banks since these transactions occur on a regular basis. The purpose of establishing rural banks was to provide sufficient institutional credit to rural people. The rural credit banks provide help to develop the agricultural sector of the economy since most rural dwellers are farmers or work in the agricultural-related enterprise (Flora, 2018). These rural banks function with the added goal of developing rural areas. Property owners who reside in rural areas also encourage these banks to be developed in such areas. In this way, rural banks also provide a way for such people to deposit their money.

Kwapong (2013) pointed out the following functions of rural banks;

i. $\quad$ They mobilize means from their catchment areas and lend them to deserving applicants in these areas. Decisions are taken locally, and matters relating to disbursement and credit are attended to without delay.

ii. They help to enhance businesses in rural communities by helping them improve upon their various activities through the delivery of banking services.

iii. The promotion of rural banks in cocoa-growing areas enables farmers to make purchases of cocoa through established payment systems.

iv. Rural banks function by providing credit for the construction of social infrastructures such as schools, health centers, and pipe-borne water.

v. Rural Banks helps rural children by awarding scholarships to needy but brilliant students.

vi. They help to enhance smallholder agriculture in the rural communities by helping farmers and small-scale operators in various trades to improve upon their activities.

vii. They help to inculcate banking culture amid people in the catchment areas of rural banks.

Rural banks were set up to ensure that rural communities in Ghana have access to banking facilities and a source of micro-finance for rural enterprises' development (Agyapong, 2016). Usually, the commercial banks are reluctant to lend to rural communities because of the risk and cost associated with it. Therefore, rural banks represent the only source of financing for rural dwellers.

In that regard, rural banks make a significant contribution in ensuring poverty and rural-urban migration are reduced to the minimal. The banks undertake a mix of microfinance and commercial banking activities structured to satisfy the need for rural areas (Alhassan, 2018).

Some of the rural banks have subsidiary companies, such companies engaged in consumer credit and other developmental activities (Agyapong, 2016). Rural banks dedicate part of the earning to meet social development administration and support the needy in their respective communities (Nair \& Fissha, 2010). A number of these banks have specific gender programs focusing on women-in-development and credit-with-education activities for women in rural communities Asiedu-Mante (, 2011). Therefore, rural banks are the primary organization for financial intermediation and capital formation for people in rural communities.

\subsubsection{Services provided by Rural Banks}

\subsubsection{Payment}

Payment services are one of the main activities or services rendered by rural banks (Erwin, Abubakar \& Muda, 2018). The apex bank, which is a sister of the national clearinghouse, is the medium through which rural banks provide the payment service (Boateng, 2016). Rural bank cheques were given the same legitimacy as cheques issued by other financial organizations through the institution of magnetic ink character recognition (MICR). Rural bank cheques were not accepted by many institutions and commercial establishments before the introduction of magnetic ink character recognition (MICR) cheques guaranteed by the apex bank (Appiah, 2016). A rise in the amount of cheques for clearing by an average of forty-three percent a year with the introduction of the chequeclearing system in 2002. The central, local governments and private companies use the rural banks to make salary and pension payments to their employees in rural areas because of their location and network of branches (Nair \& Fissha, 2010). In particular, the salary payment system allowed rural banks to consolidate their wage loan products, which are firmly tied with the salary transfers. Rural banks are also used by the licensed buying companies (LBC's) to pay cocoa-producing farmers in their catchment areas.

\subsubsection{Social Investments}

As part of the rural bank's social responsibility to the rural communities where they operate, most rural banks support social development activities in rural areas (Flora, 2018). Such development activities supported by the rural banks include awarding scholarships for girls and medical students as well as financing of infrastructural projects such as the building of schools, community libraries and the construction of community roads. Agyapong 
(2016) asserted that rural and community banks have also acquired recognition in their communities as a locally controlled financial institution rooted in the community through these activities.

\subsubsection{Financial intermediary.}

Rural banks act as financial intermediaries by providing basic services such as loan facilities, savings, and payments (Erwin et al., 2018). Several products and services are offered within each of these categories. Generally, rural banks also support community development services due to community-owned nature. Rural and community banks offer unique products and service for particular target groups on government behalf And donor-funded initiatives such as the Microfinance and Small Lending Center (MASLOC), the Social Investment Fund, the community-based rural development project, and the millennium development authority as financial institutions actively supported by the government.

Most rural banks use various methods, such as electronic and print media, to promote their products and services (Nair \& Fissha, 2010). Some banks, for instance, use the local FM radio to broadcast information about services available and to promote their products (particularly microfinance). The move has been successful in reaching many clients in remotes parts of the operational area. (Nair \& Fissha, 2010).

\subsubsection{Deposits.}

Rural banks have all the general savings items, including regular savings accounts, current accounts, susu account, and fixed deposit account (Nair \& Fissha, 2010). Generally, savings accounts are the largest share of deposit portfolio in rural banks. Low-interest rates are offered to these accounts, yet, and often negative when inflation is taken into account. Unlike in most commercial banks, rural banks do not require a high minimum balance to maintain a savings account.

The susu deposit is a special deposit offered by rural banks. These deposits are weekly or daily savings deposits that are collected by susu collectors (mobile bankers), who are either employees of rural banks or hired officers. These deposit and deposit collection technology builds on the traditional system of susu collectors in Ghana (Koduah-Boateng, 2016). The susu collectors (mobile bankers) mobilize daily deposits by visiting individual customers at their houses and business premises (Banson, Sey \& Sakoe, 2012). A mobile banker has a schedule and an agreed plan with customers and collects the amount of deposit according to the agreed plan. Banson et al. (2012) pointed out that one mobile banker can visit almost 30 customers per day. The majority of mobile bankers are women, whereas most of the participants are women. Typically, no interest is paid on susu deposit, and depositors pay a fee for the service.

Special savings mobilization systems are used by the banks (Nair \& Fissha, 2010). The susu method is used by many banks to mobilize money from customers. Deposit mobilization centers are used by some banks which operate during the market days. A unique deposit product that targets specific target groups such as petty traders and drivers, or purposes such as children's education are offered by some rural banks.

With the exception of mobilizing local savings and meeting the credit needs of small and medium-scale entrepreneurs and farmers, rural banks were envisaged as taking up the task on implementing programs of supervised credit, providing ancillary banking service, supplying inputs and agriculture credit, providing support in marketing, and generally helping the overall improvement of their areas of operation (Enu-Kwasi, Koomson, \& Baah-Mintah, 2013).

\subsubsection{Loans}

The major loan facilities offered by the rural banks include commercial, salary, susu and microfinance loans, overdrafts, and others (Appiah, 2016). Microfinance loans, as well as susu loans, are the two special loan products that most directly benefit the low-income population (Banson et al., 2012). An important portion of the salary loans, however, would also be considered microloans in the Ghanaian perspective. Kwarteng (2017) pointed out that the loan portfolio of rural banks is larger than the sum of the money lenders and susu loan portfolios; hence rural banks provide a much stable source of credit for rural people.

2.2.3.5 Business Advisory Services (BAS)

Business advisory services are essentially the king of services that are provided by financial institutions to help customers gain knowledge on how to manage their businesses or prospective ventures (Shaikh \& Karjaluoto, 2018). Over the years, BAS has evolved from the provision of inquiries to customers and incorporate into premier banking. Chandra (2017) suggested that BAS may involve advisory services on wealth management, banking accounts, mutual funds, insurance, savings, and investment. Major commercial institutions have incorporated BAS as part of the services provided to customers on a regular basis. Chandra (2017) again suggested that providing BAS implies the need to set up a physical desk for that purpose. This study looks at the relationship between companies' advisory services and rural development in the Wenchi municipality.

\subsubsection{Major Banking Credit Products}

\subsubsection{Microfinance loans}

Microfinance loans are granted to groups of individuals to finance small and micro income-generating activities (Jose \& Chacko, 2017). At some banks, the group is the borrower, whereas, for others, each member of the group is a borrower. In both cases, the group is equally liable for the loan. The size of the microfinance loan ranges 
between GHф500 and GHф1000 (Baidoo \& Baidoo, 2016). The repayment period for a microfinance loan is four to six months, and the interest rate ranges between 30 and 36 percent.

\subsubsection{Susu loans}

Susu loans are granted to individuals following a three-month daily susu deposit (Koduah-Boateng, 2016). The amount and term of susu loans are similar to that of microfinance loans, but susu loans are granted to individuals whereas microfinance loan is a group loan. Susu loans are normally granted to petty traders since they are the majority who patronize the susu product. The interest rate ranges from 30 to 32 percent.

\subsubsection{Salary loans}

Workers or individuals who receive their salaries from the rural banks are granted these loan facilities (Appiah, 2016). The bank deducts the cash interest installment immediately from the salary payments. Wage loans are used for business and investment needs, as well as social purposes. The loan facility is granted based on the customer's net salary and affordability. A wage loan's average term is 48 months, and the interest rate varies from 29 to 30 percent.

\subsubsection{Commercial loans}

Individual entrepreneurs and companies can access commercial loans for working capital or to expand their business (Quartey, Danquah \& Iddrisu, 2017). Loans are usually granted based on the loan appraisal processes such as Character, Ability, Margin, Purpose, Amount, Repayment, and Insurance (CAMPARI) (Owusu-Dankwa \& Gyamfi, 2013). For a loan acquisition, the maximum term is 36 months, and the interest rate ranges between 28 and 35 percent. Most commercial loans are between GHф1000 and GHф5000 (Baidoo \& Baidoo, 2016).

\subsubsection{Rural Banking and Financial Development}

Atta Mills and Amowine (2013) defined rural bank as a banking object which is co-operative in character but presents a much wider range of services. The basic function of rural banks is to meet the financial distress of medium and small-scale entrepreneurs, farmers, and savings mobilization. They are also seen as taking up the task of implementing programs of supervised credit, providing additional banking services, supplying inputs and agricultural credit, providing assistance in marketing, and generally helping the overall development of the banks' operational areas.

At the heart of rural banking is the need to facilitate financial development in rural communities (Bateman \& Chang, 2012). Bateman and Chang (2012) also argued that the establishment of financial institutions in the rural regions is to cater to the banking needs of the local people and provide access to capital for the poor, which collectively with human capital helps reduce poverty in rural communities. Providing material capital to ordinary people strengthens their sense of dignity, and this can assist in empowering the rural dwellers to engage in financial enterprises, which helps raise their standard of living in rural communities (ibid).

Lack of financial development is a cause of poverty, which is a complex issue and is challenging to define, as there are various dimensions to poverty. Ravallion (2017) defined poverty as a situation of poor health facilities, low level of education, malnutrition, and a lack of involvement in decision-making.Dickerson and Popli (2018) perceived poverty not only as a lack of income, education, or health, yet also on a broader range, lack of voice, need of empowerment, and lack of good governance. Dickerson and Popli (2018) defined poverty as the deprivation of basic capabilities rather than simply as a low level of profit, which is the standard basis for identifying poverty. They identified five dimensions of poverty: lack of political space, economic space, social space, transparency, and protective security (ibid). Dickerson and Popli (2018) viewed poverty as depicted along these five dimensions, which limit people's ability to develop their skills and functions effectively.

A critical assessment of the literature revealed that at the heart of financial development is the whole gamut of basic needs. Typically, a person is considered poor if he/she does not have the capabilities to meet basic needs. Poverty is not a pure income shortage but goes beyond that to take into account the social background in which he stays, including access to credit, which in turn enhances ability (Akindola, 2009).

As development agents, rural banks have, over the years, brought services to the doorsteps of people, most importantly, rural folks or dwellers. With these, rural banks have succeeded in instilling in the rural dwellers the habit of banking in the form of savings and borrowing. Rural banks have contributed immensely to the mobilization of savings and have granted loans and overdrafts to several productive ventures to promotes development activities and enhance the socio-economic lives of rural dwellers (Tetteh \& Antwi, 2013). Access to financial services has been identified by Cole, Sampson, and Zia (2011) as a potential tool in raising productivity and incomes of small and micro-entrepreneurs.

The provision of credit increases the individual's productivity, and also increased social equity by improving the individual's income (Firth \& Yamey, 2013). Such increases in income can be seen as an avenue for greater equity in national consumption rates and a fairer distribution of economic opportunities (Firth \& Yamey, 2013; IFAD, 2012). The international fund for agricultural development (IFAD) (2012) report showed how access to credit and the services provided by rural banks and micro-financial institutions affects household welfare outcomes.

Some studies have pointed out that the introduction of the bank in rural areas enhance the livelihood of rural dwellers. One of such studies is research by Patel and Chavda (2013), the research revealed that the establishment 
of banks in rural areas of India spurred entrepreneurship, structural change, and poverty reduction. It was also asserted that access to banking, particularly finance, may be critical in enabling poor rural residents to begin new macroeconomic activities, thereby exiting poverty (ibid).

Scholars such as Otoo (2012) remained skeptical about the role that rural and microfinance institutions play in improving the living conditions of people. He pointed out that rural banks and micro-credit are not a panacea for poverty alleviation since, in some cases, most ordinary people have been made worse-off. However, some scholars such as Afriyie and Akotey (2013) sees rural banking institutions as agents of financial development and/or poverty reduction.

Empirical studies showed that rural banks help the poor to meet basic needs and also protect them against risk. This consequently results in an improvement in household economic outcomes. Rural banks create access to productive capital for the poor, which, together with human capital development through education and training, enables the poor to move out of poverty (Afriyie \& Akotey, 2013).

\subsubsection{Challenges Rural Banks Face in providing Services to Rural People.}

With regards to the services rural banks provide to its customers and the rural community as a whole, there are some challenges the rural bank faces in delivering its functions. Some of these challenges are structural, organizational challenges, while others have to do with extrinsic factors. These challenges usually pose a risk to the functions of the rural bank in delivering its core mandate. Rural banks are particularly exposed to the following risks.

$\begin{aligned} \text { i. } & \text { Credit risk } \\ \text { ii. } & \text { Default risk } \\ \text { iii. } & \text { Liquidity risk } \\ \text { iv. } & \text { Reputation risk } \\ \text { v. } & \text { Information risk }\end{aligned}$

\subsubsection{Credit risk}

Bielecki and Rutkowski (2013) defined credit risk as to the probability of loans not being repaid on time or paid at all. It can also be explained as the chance that a debtor will not pay at all, that is the principal and interest. Credit risk means that repayment may be delayed or ultimately not paid and can, in turn, cause cash flow problems and affect the institution's liquidity. The credit risk is despite innovation in the financial services sector; still, the single major cause of financial institutions failed.

\subsubsection{Default risk}

Default risk is the probability a customer will not meet the timely payment on their loan or credit obligations (Bennett, Güntay \& Unal, 2015). Rural Banks are usually exposed to default risk in a number of forms of credit advances. The higher the danger, the higher the return rate. Addae-Korankye (2014) pointed out that rural dwellers are not willing to pay a credit or loan with a higher return rate in the case of a default, which makes rural banks less likely to advance credit to these rural dwellers.

\subsubsection{Liquidity risk}

Liquidity risk applies to the potential inability of a financial institution to accommodate depositors' demand to withdraw their funds because of a lack of available cash (Adrian \& Ashcraft, 2016). Rural banks may face liquidity risk when the banks cannot meet its short-term debt obligations. In the cases of liquidity risk, Reddy and Prasad (2011) pointed out that rural banks may not turn an asset into cash without giving up resources and profits due to a lack of buyers or an unstable market? Thakor (2015) suggested that the liquidity risk of financial institutions should be taken seriously as some big banks have collapsed or faced insolvency issues because of liquidity problems during the 2008 financial crisis.

\subsubsection{Reputation risk}

Reputation risk is the risk to profits or capital arising from negative public opinion (Gatzert, Schmit, \& Kolb, 2016). For transforming rural banks, this risk can expand exponentially as the institution shifts from being a creditonly institution to one that takes on responsibility for mobilizing and intermediating public deposits. Successful savings mobilization requires that the institution be perceived as stable and trustworthy. Any damage to the institution's reputation can have significant implications for the bottom line (Lin-Hi \& Blumberg, 2018). The present study examines the challenges faced by rural banks giving out credit to rural dwellers.

\subsubsection{Information risk}

It is challenging to accurately assess the profitability of small and medium scale enterprises, the abilities of these entrepreneurs and industrialists, and the prospect that the customers will repay their loans, which are the main creditworthiness requirements applied by the rural banks. Rural banks also faced challenges with information asymmetry whereby rural dwellers deliver partial information. Hayford (2012) referred to information asymmetry as the disparity between the information presented to the rural banks by the customer seeking credit and the actual information in their books.

\subsubsection{European Network for Rural Development}

One approach to rural development that has had practical use is the European network for rural development. 
European network for rural development defined rural development in five main dimensions, and any agency that is motivated to bring about sustainable rural development should be able to implement programs in these areas (Hartman, 2015). These are social, economic, environmental, political, and technological dimensions. Rural banks are facilitators of rural development through the provision of rural credits, which helps in transforming the rural economies.

The operation of the rural banks in rural communities can facilitate the expansion and subsequent development of the areas. The process starts with the mobilization of funds that are locked up in the rural areas. This obligation is executed through products like saving, current, and fixed deposit accounts, etc. Subsequently, the amount mobilized as funds if given in the form of loans, advances, and overdrafts to the targeted population will solve the credit problems in the rural communities.

As the beneficiaries invest the credit in agriculture and other rural ventures, there will be an increase in output and productivity, increase income, and an enhanced standard of living. The increase in output may make room for the intensification of agriculture, which can also create employment in rural areas. As the process continued, the rural areas eventually will open up and give room for other stakeholders and institutions to invest in the area. This process can be linked to the improved agricultural approach to rural development and falls under the economic dimension of the European network for rural development concept.

\subsubsection{Conceptual Model}

The integrated approach to rural development concept has been adapted to suit the purpose of this study. The present study of assessing the relationship between loans and advances and rural development aligns with the impact rural banks have on rural development. The independent variable includes loans and advances and business advisory services provided by rural banks. The dependent variable is the performance of rural banks in rural development in the Wenchi Municipality. The contention of this study is to find out the relationship between credit and business advisory services rendered out to rural dwellers and rural development. This study seeks to investigate and determine the effects of credit and business advisory services in advancing rural development. Figure 2.1 below shows the conceptualized model of the study.

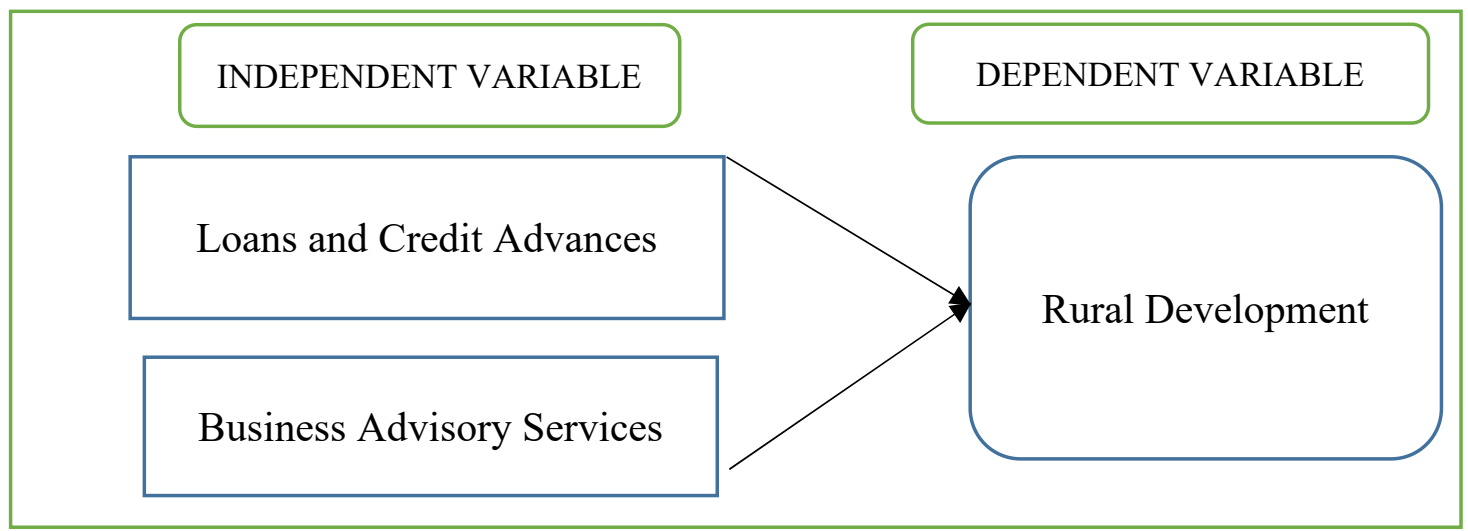

Figure 1: Conceptual Model for the Study

\subsection{Theoretical Framework}

The term "development" has had several meanings over the years. In the 1960s, development became synonymous with technological improvements and rapid economic growth (Hanushek, 2013). More recently, definitions of development have included improvement in material conditions, holistic and multi-dimensional development, good health, education, increased consumption, gender equality, human freedom and sound environment (Pattanaik, Rustagi, Menon \& Farooquee, 2018)

The concept of rural development has emerged through socio-political struggles and debates. A lot of studies have been done in this respect, and it is evident that rural development is regarded as a force that will revitalize agriculture. Any critical discussion on this issue must begin with the acknowledgment that, as yet, we have no comprehensive definition of rural development.

Rural Development is currently seen as a multi-level, multi-actor, and multi-facet process. It is said to be a multi-level process that is rooted in historical traditions. At all levels, it has developed as a series of responses to the earlier theory of modernization, which had education and technology as the bases. It is the complex institutional setting on the processes involved in rural development that makes it multi-actor. The ride towards a decentralized rural policy approach, which is a locality and the newly emerging relations between the locals and the globe is a major principle designed to strengthen the process. Rural development is also multi-facet in nature. It releases into a wide array of different and sometimes interconnected practices (Pattanaik et al., 2018).

With respect to the theories on rural development, there is no dominating theory in the business of banking 
literature that explains the process development of regions to financial inclusion and provision. As a result, there is no definitive "theory of rural development, providing a framework analyzing all the aspects of rural development (Guinjoan, Badia \& Tulla, 2016).

For the purposes of this study, rural development is used to denote the actions and initiatives taken to develop the standard of living in non-urban neighborhoods, countryside, and remote villages. All over the world, a lot of approaches have been adopted to propel growth in rural areas. This study is anchored on the integrated approach to rural development. Three approaches that are closely related to this study are enumerated below.

\subsubsection{The Social Amenity Approach}

The social amenity approach is embarked on with an emphasis on the provision of basic social amenities (educational, health, recreational, water, etc.) for the rural communities (Vaznoniene, 2015). The provision of social amenities and the development of the cultural and historic sites of the communities are undertaken to open up for tourism and investment (Murphy, 2012).

This approach to rural development is expensive since it has to cover a wide range of valuable social services. However, the economic, labor and organizational support for efficient distribution of social services are often limited in rural areas, and hence the provision of social amenities very expensive. It is also apparent that rural development is much more than the provision of social amenities.

\subsubsection{Improved Agriculture Approach}

The improved agriculture approach places emphasis on improvement in agriculture through the provision of credit and the use of technology in rural areas. This is because agriculture is the major source of income in rural areas and has the potential of transforming rural economies. The approach, therefore, seeks to strengthen the backward and forward linkages along the food chains, ensuring food security for the poor and vulnerable through partnerships with development partners in providing programmatic support to agriculture. The approach also ensures the provision of well-functioning agricultural markets that connect most rural households as either sellers of produce, buyers of food, or both. Access to remunerative and reliable produce markets has the tendency of enabling farming households to commercialize their stock systems and increase their farm incomes.

However, it is usually a challenge for poor rural people to seize fulfilling moments in produce markets and to cope well with the associated risks. Then again, there is the problem of stagnating food productivity and production, lack of access to rural finance, infrastructure, technology, lack of markets, limited nonfarm income opportunities and the threat of climate change and volatility of food prices (Dupas, Green, Keats \& Robinson, 2012).

\subsubsection{Integrated Approach}

Bhalla, Kumar, and Rangaswamy (2018) described integrated rural development as a continuous process involving outside intervention and local aspirations which aim at attaining the betterment of groups like people living in rural areas and to maintain and enhance rural values through the redistribution of central resources, reducing related disadvantages for trial and finding new ways to reinforce and utilize rural resources. It is integrative in the sense that, as opposed to central development, the integrated approach is controlled and managed locally. Although this approach ensures the participation of all stakeholders in rural development, the challenge is that it delays the development process and quite expensive to implement. In all the approaches listed above, the need for finance stands out, and all the approaches require one way of funding or another.

\subsection{Empirical Framework}

Several studies have been done on the role rural banks play in rural development. A study was conducted by Akudugu (2011) on the impact of rural banking on rural communities. The purpose of the study was to find out how financial capital from rural banks contributes to the development of the livelihood of women farmers who constitute the most vulnerable and disadvantaged group in Ghana and other developing countries. The study found that rural banks were found to have positive contributions to the livelihood development of the women farmers and the poor in general.

Anti (2012) also conducted a study on the impact of rural banks on rural development in the Ashanti Region of Ghana. The study examined the extent to which Rural Banks help in expanding and developing rural communities through the mobilization of funds and the provision of credit facilities to these communities. The study also sought rural dwellers' perception of the role of Rural Banks as facilitators of Rural Development. The study made use of seven Rural Banks and ninety - five rural dwellers from seven rural communities where agencies of the selected banks are located. The study found that the extent to which the banks assisted communities in rural development depended on their financial strength. The author concluded rural banks are unable to fully fulfill the purpose for which they were created.

Another study by Uma (2012) was conducted on the impact of rural banking on farmers. The main objective of the research was to identify the key factors that impact the farmers. After effective research, it was found out that the higher the interest rate, the lower the demand for credit among the farmers and suggested that interest rate should be reviewed when granting loans to farmers. 
Devi (2012) conducted another study on the "effects of rural banking scheme on the investment potentials of rural farmers in Ebonyi State." The purpose of the research work was to find out the impact of rural banking scheme on the investment potential of rural farmers. The findings from the study showed that there was no significant impact on crop loans in irrigated villages. However, the impact of crop loans on semi-irrigated and nonirrigated villages was significant.

The study also revealed that certain advantages could be enjoyed through improved technology with the efforts of the rural bank for the benefit of farmers. The study concluded that cooperative credit has a significant impact on rural enterprises, especially on agricultural enterprises.

Afful, Herjlik, and Doucha (2015) also conducted a study to examine the effect of the activities of financial organizations on rural communities. The study sought to find out the role of rural banks in agricultural development and food security of the Birim South District in the Eastern Region of Ghana. The research found that there was a positive effect of the activities of rural banks on rural dwellers in terms of providing financial security in times of difficulty. The study concluded that rural banks help educate rural people on the importance and management of financial issues.

Another study by Opoku and Adjei (2016) explored the credit management practices of Odotobri rural banks in the Obuasi municipality. The study indicated that the three significant factors that determine credit are collateral security, monthly net profit, and level of savings. The study recommended that, among other things, the due process should be taken in issuing out credit, which will consequently reduce the high default rate among rural people. Another recommendation was that training programs should be organized for bank officials to help facilitate the ways of serving rural dwellers well.

Agyapong (2016) conducted a study on the impact of rural banks on farmers. The aim of the study was to recognize the impacts of rural banking on rural farmers, and it was found out that all the farmers saved their monies with a specific financial institution. The major type of account opened by the farmers was the savings account. This author reported that most rural people had ever applied for a loan while others did not because they were uncomfortable with the high-interest rates associated with the loans. Some of the requirements needed to borrow money were a viable business proposal or a business plan, four guarantors who are salary workers, and collateral security. The reason why the banks demanded these items was to protect the interest of the bank and propel customers' commitment to payment of the loan. In addition, the interest rates were too high for the small or peasant farmers to cope with. This was because those who borrowed money from the bank found it difficult to pay the loans back.

Adenle, Azadi \& Manning (2018) pointed out that for agricultural development, credit remains an important input that ensures enough working capital as well as infrastructural development. Agricultural credit and agricultural development go by hand in hand. Hence the farmer should be provided with adequate and cheap credit. It was supported by Rahman, Hussain, and Taqi (2014), who suggested that without cheap credit, it will not be possible for small and limited farmers to survive. Adenle, Azadi \& Manning (2018) suggested in their study that a better institutional credit facility was highly essential for agricultural growth. They recommended a multi-agency approach in order to fill the gap between supply and need for credit in the agricultural sector.

From the prior discussion of the role rural banks play in rural development, it is clear that the effective functioning of rural banks in rural communities would bring about development in rural communities. This study investigated the relationship between loans and advances and business advisory services and rural development.

\subsection{Conclusion}

The present study reviewed literature that showed various studies that have provided many insights with respect to rural banks' role in rural development. The chapter reviewed literature in

- The beginning and development of rural development in Ghana (Bawumia, 2015; Dzadze et al., 2012; Nair \& Fissha, 2010).

- The various function of Rural Banks put forward by various authors in the literature (Flora, 2018; Jose \& Chacko, 2017; Agyapong, 2016; Birchall, 2012; Asiedu-Mante 2011)

- $\quad$ Services and products provided in rural banking (Erwin, Abubakar \& Muda, 2018; Quartey, Danquah \& Iddrisu, 2017; Boateng, 2016; Appiah, 2016; Koduah-Boateng, 2016;

- Challenges Rural banks encounter in providing services and products to rural dwellers (Bennett, Güntay \& Unal, 2015; Thakor 2015; Addae-Korankye, 2014; Bielecki and Rutkowski, 2013).

This chapter also reviewed various works on rural banks and rural development. These studies were reviewed on;

- The impact of rural banks on rural development (Anti, 2012; Akudugu, 2011).

- Influence of rural banking on business enterprises (Devi, 2012).

- Impact of rural banking on agriculture (Adenle, Azadi \& Manning, 2018; Agyapong 2016; Uma (2012).

- Credit management of rural banks (Opoku and Adjei, 2016). 


\section{Methodology}

\subsection{Type of Research}

The study employed descriptive research because it is intended to solicit information on the present status of the rural development in the Wenchi Municipality and how the credit and business advisory services from the Rural Banks in the Municipality have contributed to the rural development. Descriptive surveys interpret, synthesize, and integrate data point to implications and interrelationships (Creswell, 2013). The descriptive study determines and reports as things are. Its survey design is directed towards determining the nature of a situation as it exists at the time of the study. It is versatile and practical in that, and it identifies present conditions and points to recent needs.

\subsection{Population}

The population of the study included customers and staff of Wenchi Rural Bank, Baduman Rural Bank, and Nkoranman Rural Bank. These banks constitute the population because they are the rural banks in the Municipality under study. The population size at the time of the research was approximately 10,000 customers and 50 Bank Staff.

\subsection{Sample and Sampling Technique.}

The sample for the study was retrieved from the population. The sample size for the study was comprised of 219 consisting of 210 customers who are rural dwellers and nine rural bank staff (Credit officer, Operations manager, and Customer Service Officer) selected from the three Rural Banks; Baduman Rural Bank, Nkoranman Rural Bank and Wenchi Rural Bank for the study. The study employed stratified random sampling in grouping the banks into three strata. Simple random sampling was then used to select the respondents (customers) form each bank. In selecting the Bank Staff, purposive sampling was used to select the respondents. Purposive sampling technique was used because it enabled the researcher to pick samples that were "information-rich" (Creswell, 2017).

\subsection{Data Collection}

\subsubsection{Source of Data Collection}

The study made use of the primary source of data. The primary source of data is the data that provides raw information and first-hand experience of a phenomenon being studied (Hewson, \& Stewart, 2014). For the current study, data were collected from the study participants (respondents) and analyzed to provide answers to the objectives of the study.

\subsubsection{Instrument of Data Collection.}

The study sought data with the use of questionnaires. The questionnaire is a widely used and useful instrument for data collection, comparatively straightforward to analyze. Despite the fact that questionnaires do not provide an opportunity to collect additional information through probing, it is known that the use of questionnaires provides wider coverage and offers greater assurance of anonymity.

Two sets of questionnaires were prepared; one was prepared to solicit data from customers while another was used to solicit data from the Bank Staff of the Rural Banks. The questionnaire was devised in accordance with the research objectives of the study. The questionnaires contained Likert scale question items and closed-ended questions. The questionnaire for customers was divided into three sections. The first section sought information on the basic data of the respondents. The second section sought data on loans and advances rural banks give to rural customers, while the third section sought information on rural banks' efforts in offering business advisory services.

\subsubsection{Instrument Validity and Reliability.}

Prior to the collection of the primary data, the questionnaires were given to experts to look at it and verify if the content was reliable to collect the necessary data. To ensure that the questionnaire consistently measures what is required, the study ensured that the questionnaire items were clear as possible by stating questions in clear and simple terms. In this study, Cronbach's alpha was used to determine the reliability of the questionnaire.

\subsubsection{Procedure of Data Collection}

Data were collected with permission and assistance from authorities of the various banks. At the time of administering the questionnaires, respondents were briefed about the importance of how each question should be answered truthfully and independently. The questionnaire was then administered to the selected respondents in an atmosphere that guaranteed that they could answer the questions independently.

\subsection{Method of Data Analysis}

A simple statistical analysis was used to analyze the data gathered. Descriptive analysis was used to analyze the background information of respondents. The descriptive analysis involves using frequency counts and percentages. Inferential statistics such as regression and correlation analysis were used to determine the relationship between loans and advance to rural development. 
Diagrams were used to illustrate various findings of the study. The analysis followed an approach that is consistent with the achievement of the objectives of the study. This would ensure the study comes out with its final findings. The data were corrected for completeness and consistency, after which extraction was performed and presented in tables and charts.

\section{RESULTS AND DISCUSSION OF FINDINGS}

\subsection{Data Presentation and Analysis}

\subsubsection{Type of Account Customers Opened with the Rural Banks}

Information was sought on the type of account respondents (customers) opened with their respective banks. The conclusion revealed that sixty-nine customers opened a savings account in either of the three banks. Customers that opened the susu account and current account were fifty-seven and forty-five customers, respectively. A fixed deposit account was the account with the least number of customers (that is, 23 customers). Figure 2 shows the distribution of the type of account opened by the respondents (customers).

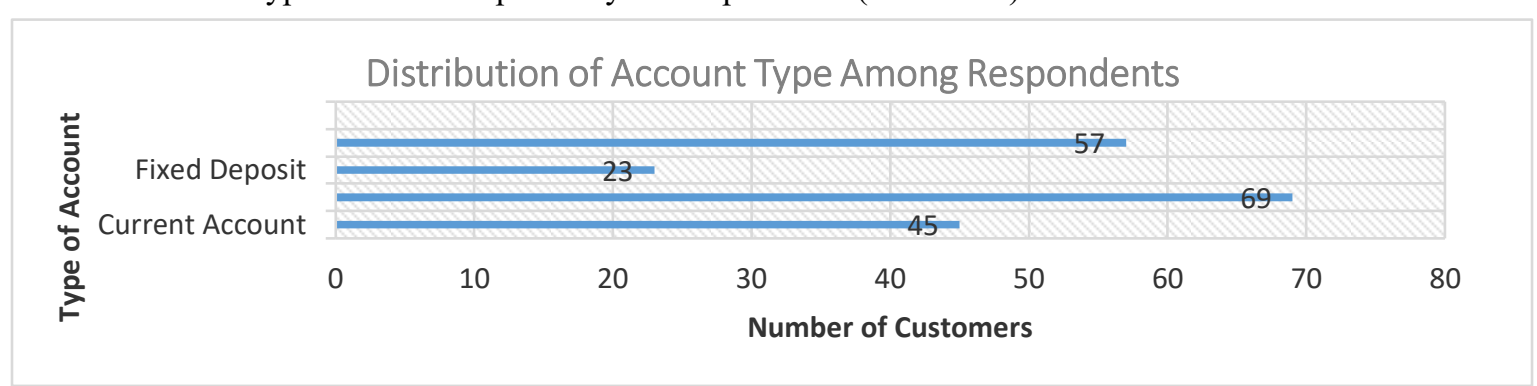

Figure 2: Distribution of Account Type among Respondents

The findings showed that savings account was the most active product operated by the rural banks in the municipality. It can be implied that most rural dwellers mainly open an account with the aim of saving money as well as to acquire a loan. The prominence of savings account among rural dwellers is in line with Osei (2016), who indicated that the active type of account operated across-section of Ghana is the savings account. The idea to save money is also reflected in the respondents' indication in the susu account as another prominent account. Alhassan (2018) also pointed out that the susu account has become an increasingly popular account among most rural dwellers.

\subsubsection{Relationship between Loans and Advances and Rural Development}

The findings of this study also established the relationship between loans and advances and rural development. Factors or indicators of loans and advances included the type of loan acquired, the purpose of the loan acquisition, and other factors. The findings again established the correlation between loans and advances and the performance of rural banks in rural development.

\subsubsection{Loan Acquisition}

The study sought information on whether the respondents ever acquired a loan from rural banks. This information was sought from the customers. The findings explicated that majority of the respondents $(62.37 \%)$ indicated they had acquired a loan from their respective rural banks before. The remaining $37.63 \%$ of the respondents indicated they had never acquired a loan from their respective rural banks. (See Table 1)

Table 1: Loan Acquisition

\begin{tabular}{lcc}
\hline Response & Frequency & Percentage \\
\hline Yes & 121 & 62.37 \\
No & 73 & 37.63 \\
Total & $\mathbf{1 9 4}$ & $\mathbf{1 0 0 . 0 0}$ \\
\hline
\end{tabular}

Source: Field Work, 2019.

\subsubsection{Type of Loan Respondents Applied For}

The study also sought to find out the type of loan respondents (customers) applied for. From the 121 respondents that indicated they had applied for a loan before in Table 4.2, 30 respondents pointed out that they applied for a personal loan while 18 indicated they applied for a business loan. Again, 15 respondents and 50 respondents specified that they applied for susu loan and microfinance loans, respectively. With regard to funeral loans, eight respondents indicated they applied for this type of loan. (See Figure 3). 


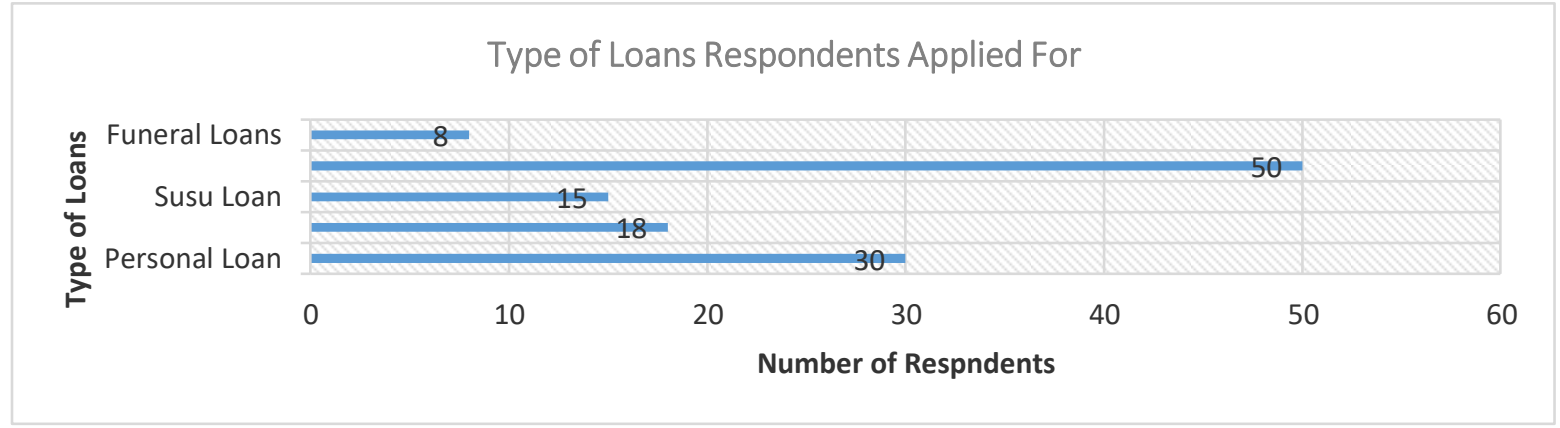

Figure 3: Type of Loan Respondents Applied For

4.1.2.3 Type of Loans Respondents Would Apply For

For customers who indicated they had never applied for a loan before, the study sought information on the type of loan they would apply for if they were inclined to do so (see Figure 4).

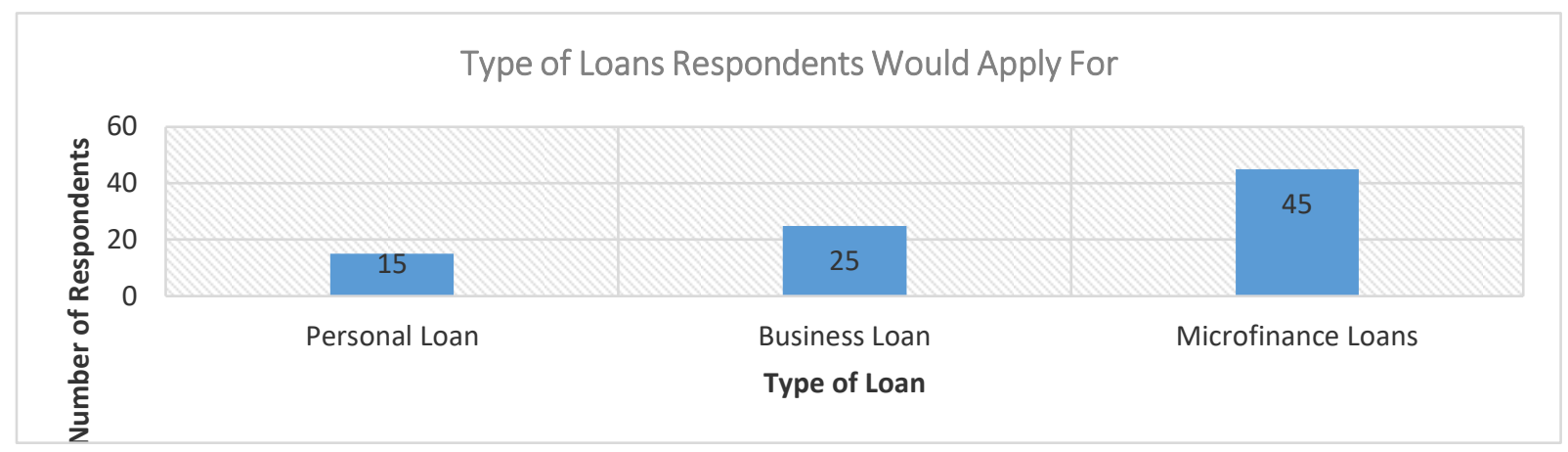

Figure 4: Type of Loans Respondents Would Apply For

The findings showed that most of the respondents that are 45 indicated they would be inclined to apply for a microfinance loan while 25 respondents pointed out they would be inclined to apply for a business loan. The number of respondents that specified they would be inclined to apply for a personal loan was 15 .

\subsubsection{Accessibility of Loans}

The study sought to find out if loans are easily accessible or granted at the various rural banks. The findings revealed that almost all of the respondents (Bank Staff), that is, $88.89 \%$ indicated that loans are easily accessible at the respective banks. $11.11 \%$ of the respondents indicated loans are easily accessible at the rural bank. (See Table 2)

Table 2: Accessibility of Loans

\begin{tabular}{lcc}
\hline Response & Frequency & Percentage \\
\hline Yes & 8 & 88.89 \\
No & 1 & 11.11 \\
\hline Total & 9 & 100.00 \\
\hline
\end{tabular}

Source: Field Work, March 2019.

\subsubsection{Loan Acquisition Duration}

The study also sought to find out the duration it takes for rural banks in Wenchi Municipality to grant loans to customers. The table shows the findings of the duration of the loan acquisition.

Table 3: Loan Acquisition Duration

\begin{tabular}{lcc}
\hline Duration & Frequency & Percentage \\
\hline Within 48 hours & 1 & 11.11 \\
Within one week & 5 & 55.55 \\
Within a month & 3 & 44.44 \\
\hline Total & $\mathbf{9}$ & $\mathbf{1 0 0 . 0 0}$ \\
\hline
\end{tabular}

Source: Field Work, March 2019.

From the findings in Table 3, most of the respondents (Bank Staff), that is, 55.55\% indicated the banks are able to grant loans within one week after application. Three respondents $(44.44 \%)$ specified that loans could be granted within a month after application, while just one respondent $(11.11 \%)$ indicated loans could be granted within 48 hours after application.

\subsubsection{Reasons for Loan Acquisition}

Table 4 shows the reasons for which customers would seek for a loan from their respective rural banks. 
Table 4: Reasons for Loan Acquisition

\begin{tabular}{lcc}
\hline Reason & Frequency & Percent \\
\hline Business Purpose & 62 & 32.0 \\
Building, renovation and/construction & 27 & 14.0 \\
Educational related Issues (e.g., Fees) & 36 & 18.5 \\
Land Acquisition & 31 & 16.0 \\
Funeral Purpose & 14 & 7.2 \\
Purchasing of Vehicle & 8 & 4.1 \\
Other Purposes & 16 & 8.2 \\
Total & $\mathbf{1 9 4}$ & $\mathbf{1 0 0}$ \\
\hline
\end{tabular}

Source: Field Work, 2019.

From Table 4, the results showed that sixty-two respondents $(32.0 \%)$ indicated business purposes would be the key factor in acquiring a loan. Twenty-seven respondents $(14.0 \%)$ pointed out that building, renovation, and/construction would be the purpose of seeking a loan. Respondents that also indicated that related educational issues like paying school fees and buying stationery would be the reason to acquire a loan were thirty-six (18.5\%), while thirty-one respondents $(16.0 \%)$ indicated that they would seek for a loan from their rural banks for the purpose of acquiring land. Fourteen respondents (7.2\%) also indicated that their major reason to acquire a loan from a rural bank would be for a funeral purpose. Again, eight respondents $(4.1 \%)$ specified that they would seek a loan from their rural banks for the purpose of purchasing a vehicle while sixteen respondents $(8.2 \%)$ also pointed out that they would seek a loan from their rural bank for other purposes.

\subsubsection{Role of Loans and Advances in Rural Development}

The study also sought information on the role loans and advances played in rural development. The question item on the questionnaire was to find out if loans and advances offered by rural banks to customers helps them to set up businesses or enterprises for an increase in rural productivity. The findings are displayed in Table 5

Table 5: Role of Loans and Advances in Rural Development

\begin{tabular}{lcc}
\hline Response & Frequency & Percent \\
\hline Not at All & 85 & 41.87 \\
Rarely & 39 & 19.21 \\
Sometimes & 31 & 15.27 \\
Most Often & 14 & 6.90 \\
Not Sure & 34 & 16.75 \\
\hline Total & $\mathbf{2 0 3}$ & $\mathbf{1 0 0}$ \\
\hline
\end{tabular}

Source: Field Work, 2019

From Table 5, a greater number of the respondents, that is 85 respondents $(41.87 \%)$, indicated that loans and advances do not contribute to rural development while a smaller number, that is 14 respondents $(6.90 \%)$ pointed out that loans and advances most often contribute to rural development. Respondents that specified loans and advances rarely contribute to rural development were $39(19.21 \%)$, while 31 respondents $(15.27 \%)$ also indicated loans and advances sometimes contribute to rural development. For respondents that were not sure loans and advances contribute to rural development were 34 (16.75\%).

4.1.3 Correlation between Loans and Advances and Role of Loans and Advances in Rural Development Further analysis was conducted to determine the relationship between loan acquisition in the rural banks and the performance of rural banks in rural development using Kendall's tau-b correlation to determine the relationship among the 203 respondents.

Table 6: Correlation between Loans and Advances and Role of Loans and Advances in Rural Development

\begin{tabular}{llcc}
\hline & & Performance of Rural Banks & Loans and Advances \\
\hline Performance of Rural Banks & Correlation Coefficient & 1.000 & $-.583^{* *}$ \\
& Sig. (2-tailed) & .000 \\
Loans and Advances & $\mathrm{N}$ & 203 & 203 \\
& Correlation Coefficient & $-.583^{* *}$ & 1.000 \\
& Sig. (2-tailed) & .000 &. \\
& $\mathrm{~N}$ & 203 & 203
\end{tabular}

**. Correlation is significant at the 0.01 level (2-tailed).

From table 4.6, there was a strong but negative correlation between loan acquisition and performance of rural banks in rural development, which was statistically significant $(\tau b=-0.583, \mathrm{p}=0.000)$.

\subsubsection{Relationship between Business Advisory Services and Rural Development}

The indicators or factors used in determining the relationship between business advisory services and rural development included whether rural banks offered business advisory services, determining the kind of business advisory services rural banks offered, and the benefits customers derived from the business advisory services the 
rural banks provided. The findings also established the correlation between business advisory services and the performance of rural banks in rural development.

\subsubsection{Respondents Feedback on the State of Business Advisory Services in Rural Banks}

Information was sought on whether rural banks offered business advisory services. From the findings of the study, 118 respondents (customers) pointed out that rural banks do not offer business advisory services. However, 42 respondents (36 customers \& 6 bank staffs), indicated that rural banks offered business advisory services. Twentyone respondents ( 18 customers \& 3 bank staffs) were of the opinion that rural banks sometimes rendered business advisory services to customers. Also, seven respondents specified that rural banks most often rendered business advisory services to customers. Fifteen respondents indicated that rural banks rarely rendered business advisory services to customers. (See Table 7).

Table 7: State of Business Advisory Services in Rural Banks

\begin{tabular}{lcc}
\hline Response & Frequency & Percent \\
\hline Yes & 42 & 20.69 \\
Sometimes & 21 & 10.34 \\
Most Often & 7 & 3.45 \\
Rarely & 15 & 7.39 \\
No & 118 & 58.13 \\
\hline Total & $\mathbf{2 0 3}$ & $\mathbf{1 0 0}$ \\
\hline
\end{tabular}

Source: Field Work, 2019

From the findings, it can be inferred that while business advisory services are part of the services rural banks offer, it is not actively sought after by customers.

\subsubsection{Type of Business Advisory Services Offered by the Rural Banks}

Information was sought on the type of business advisory services rural banks offered to customers. The information was taken from the bank staff since they were in the best position to provide that information. Some of the business advisory services offered by the rural banks in the Wenchi municipality included wealth management, banking accounts, mutual funds, and insurance, as well as savings, investment, and SME support services.

\subsubsection{Benefits of Business Advisory Services}

With regards to the benefits respondents derived from business advisory services, information was sought from both the customers and the bank staff using a Likert Scale. Table 8 displayed the findings on the benefits of business advisory services (BAS). As shown in item A of Table 4.8, most of the respondents that are fifty percent, agreed that business advisory services help in the expansion of businesses. Thirty-one percent strongly agreed that BAS enabled individuals to expand their businesses. Twelve percent were, however, uncertain whether BAS helped in business expansion. The percentage of respondents that disagreed and strongly disagreed was five percent and two percent, respectively. The results also revealed that forty-three percent agreed that BAS helped people better manage their financial distress, as indicated in item B of Table 8 . Twenty-seven percent, on the other hand, strongly agreed that BAS helped people manage their financial distress. Twenty-four percent were also uncertain, while six percent disagreed with the notion that BAS had the benefit of helping rural people better manage their financial distress.

Table 8: Benefits of Business Advisory Services

\begin{tabular}{|c|c|c|c|c|c|c|}
\hline NoBenefit to customers & & $\begin{array}{l}\text { Strongly } \\
\text { Disagree }\end{array}$ & Disagree & Uncertain & Agree & $\begin{array}{c}\text { Strongly } \\
\text { Agree }\end{array}$ \\
\hline $\boldsymbol{A}$. Expansion of businesses & & $4(1.97 \%)$ & $10(4.93 \%)$ & $24(11.82 \%)$ & $101(49.75 \%)$ & $64(31.53 \%)$ \\
\hline $\begin{array}{l}\text { B. Help people better manage } \\
\text { distress }\end{array}$ & financial & $0(0 \%)$ & $12(6 \%)$ & $49(24 \%)$ & $87(43 \%)$ & $55(27 \%)$ \\
\hline C. Helps in loan acquisition & & $0(0 \%)$ & $8(4 \%)$ & $75(37 \%)$ & $75(37 \%)$ & $45(22 \%)$ \\
\hline D. Help manage large & on-going & $0(0 \%)$ & $0(0 \%)$ & $30(15 \%)$ & $106(52 \%)$ & $67(33 \%)$ \\
\hline
\end{tabular}

Source: Field Work, 2019.

Item $\mathrm{C}$ in Table 8 also showed that thirty-seven percent were uncertain that BAS helps in loan acquisition, while the other thirty-seven percent agreed that BAS helps in loan acquisition. Twenty-two percent strongly agreed with the notion; BAS helped in loan acquisition. Very few respondents, thus, four percent disagreed that BAS helped customers in times of acquiring a loan. As indicated on item D of Table 8 majority of respondents, that is, fifty-two percent, agreed that BAS helps manage ongoing debts or payment of old debts. Thirty-three percent also strongly agreed that BAS helps in managing ongoing debts, while fifteen percent were uncertain if BAS helps in managing ongoing debts or payment of old facility.

\subsubsection{Role of Business Advisory Services in Rural Development}

Information was also sought on whether business advisory services (BAS) played a role in rural development. The verdicts revealed that most of the respondents were not sure if BAS played a role in rural development. Respondents that indicated BAS did not play a role in rural development were 47 (23\%). Thirty-one respondents 
$(18.2 \%)$ indicated that BAS rarely played a role in rural development. For respondents that indicated that sometimes BAS played a role in rural development were $28(13.8 \%)$ while $24(11.8 \%)$ respondents indicated that most often, BAS played a role in rural development. Also, sixty-seven respondents $(33 \%)$ indicated they were not sure BAS played a role in rural development (See Table 9)

Table 9: Role of Business Advisory Services in Rural Development

\begin{tabular}{lcc}
\hline Response & Frequency & Percent \\
\hline Not at All & 47 & 23.0 \\
Rarely & 37 & 18.0 \\
Sometimes & 28 & 14.0 \\
Most Often & 24 & 12.0 \\
Not Sure & 67 & 33.0 \\
\hline Total & $\mathbf{2 0 3}$ & $\mathbf{1 0 0 . 0}$ \\
\hline
\end{tabular}

Source: Field Work, 2019

4.1.5 Correlation between the Status of Business Advisory Services (BAS) and Role of Business Advisory Services in Rural Development

Further analysis was conducted to determine the relationship between the status of business advisory services (BAS) in rural banks in the Wenchi municipality and the role of business advisory services in rural development. The analysis was done using Kendall's tau-b correlation to run and determine the relationship among the 203 respondents. Table 10 presents the results of the correlation.

Table 10: Correlation between the Status of Business Advisory Services (BAS) and Role of Business Advisory Services in Rural Development

\begin{tabular}{llcc}
\hline & & Role of BAS & Status of BAS \\
\hline Role of BAS & Correlation Coefficient & 1.000 & $-.765^{* *}$ \\
& Sig. (2-tailed) & .000 \\
\multirow{5}{*}{ Status of BAS } & $\mathrm{N}$ & 203 & 203 \\
& Correlation Coefficient & $-.765^{* *}$ & 1.000 \\
& Sig. (2-tailed) & .000 &. \\
& $\mathrm{~N}$ & 203 & 203 \\
\hline
\end{tabular}

**. Correlation is significant at the 0.01 level (2-tailed).

From table 4.10, there was a strong, positive relationship between the status of business advisory services in rural banks and the role of rural banks in rural development, which was statistically significant $(\tau b=0.765, p=$ $0.000)$.

\subsubsection{Challenges Faced by Rural Banks in Developing Rural Communities}

The results of challenges faced by rural banks in developing rural communities were grouped into two categories. The first section presented results on the challenges faced by rural banks in giving out loans and advances, and the other section presented findings on the challenges faced by rural banks in rendering business advisory services to their customers. Information on these challenges was sought from the staff of the three rural banks. The results were analyzed as percentages of the total number of staff as respondents (9).

\subsubsection{Challenges Faced by Rural Banks in Giving Out Loans and Advances}

Information on challenges faced by rural banks in giving out loans and advances were obtained using a five-point Likert scale. Information on these challenges was sought from the staffs of the three rural banks. Table 11 present these findings.

Table 11: Challenges Faced by Rural Banks in Giving Out Loans and Advances

\begin{tabular}{llccccc}
\hline & Challenges & SD & D & N & A & SA \\
\cline { 2 - 6 } A. & High interest rate & $0(0 \%)$ & $1(11 \%)$ & $1(11 \%)$ & $4(45 \%)$ & $3(33 \%)$ \\
B. & High Default rate & $0(0 \%)$ & $1(11 \%)$ & $2(22 \%)$ & $4(45 \%)$ & $2(22 \%)$ \\
C. & Guarantee/Collateral Security & $0(0 \%)$ & $1(11 \%)$ & $1(11 \%)$ & $5(56 \%)$ & $2(22 \%)$ \\
D. & Poor operation of account & $5(56 \%)$ & $2(22 \%)$ & $2(22 \%)$ & $0(0 \%)$ & $0(0 \%)$ \\
\hline
\end{tabular}

Source: Field Work, 2019.

From table 11, it can be observed from item A that forty-five percent of the respondents (Bank Staffs) agreed that high-interest rate was a challenge rural banks faced in granting loans and advances to their customers. Thirtythree percent also indicated they strongly agreed that high-interest rate was a challenge rural banks encounter in giving out loans and advances to customers. However, eleven percent disagreed that high-interest rate was a challenge faced by rural banks in granting loans and advances to customers, while another eleven percent were also uncertain high-interest rate was a challenge to rural banks in granting loans and advances to customers. As indicated in item B of Table 11, forty-five percent of the respondents agreed that high default rate posed as a challenge to rural banks in terms of granting loans and advances while twenty-two percent strongly agreed with the notion that high default rate was a challenge rural banks encounter in giving out loans and advances. Another 
twenty-percent were uncertain high default rates posed as a challenge to rural banks. Eleven percent, however, disagreed that a high default rate was a challenge encountered by rural banks in granting loans and advances. From item $\mathrm{C}$ of Table 11, it showed that fifty-six percent of the respondents agreed collateral security was a challenge rural banks faced in granting loans and advances to their customers. Twenty-two percent also indicated they strongly agreed that collateral security was a challenge rural banks encounter in giving out loans and advances to customers. However, eleven percent were uncertain collateral security posed as a challenge to rural banks in granting loans and advances to customers. Also, another eleven percent also disagreed with the notion that collateral security was a challenge rural banks faced in granting loans and advances to customers. Also, as observed from item D of Table 11, fifty-six percent strongly disagreed that lack of proper bookkeeping was a challenge rural banks faced in granting loans and advances to customers. However, twenty-two percent disagreed that lack of proper bookkeeping posed as a challenge to rural banks in giving out loans and advances. Twenty-two percent were also uncertain lack of proper bookkeeping was a challenge rural banks encounter in granting loans and advances to customers.

\subsubsection{Challenges Faced by Rural Banks in Rendering Business Advisory Services}

Information on challenges faced by rural banks in rendering business advisory services to customers was sought from the staffs of the three rural banks using a Likert scale: Strongly Agree (SA), Agree (A), Neutral (N), Disagree (D) and Strongly Disagree (SD). The response from the bank staffs was calculated as a percentage of the total number of the staffs used for the study (See Table 12)

Table 12: Challenges Faced by Rural Banks in Rendering Business Advisory Services

\begin{tabular}{llccccc}
\hline & Challenges & SD & D & N & A & SA \\
\hline A. & Customers lack of interest & $0(0 \%)$ & $1(11 \%)$ & $2(23 \%)$ & $3(33 \%)$ & $3(33 \%)$ \\
B. Lack of qualified staff with expert knowledge & $2(22 \%)$ & $2(22 \%)$ & $3(34 \%)$ & $1(11 \%)$ & $1(11 \%)$ \\
C. Inadequate information in managing customers & $0(0 \%)$ & $3(33 \%)$ & $2(23 \%)$ & $3(33 \%)$ & $1(11 \%)$ \\
& business & & & & & \\
D. Inability to keep regular contact with customers & $0(0 \%)$ & $1(11 \%)$ & $2(23 \%)$ & $3(33 \%)$ & $3(33 \%)$ \\
E. Inability to develop new business strategies & $1(11 \%)$ & $1(11 \%)$ & $2(22 \%)$ & $3(34 \%)$ & $2(22 \%)$ \\
\hline
\end{tabular}

Source: Field Work, 2019.

From item A of Table 12, thirty-three percent agreed that customers' lack of interest in business advisory services (BAS) was a challenge to rural banks in rendering the services. Also, thirty-three percent strongly agreed that the lack of interest by customers posed as a challenge in offering BAS to customers. On the other hand, twentythree percent were uncertain, while eleven percent disagreed that lack of interest by customers was a challenge rural banks encounter in offering BAS to customers.

As observed in item B of Table 12, thirty-four percent were uncertain if the lack of qualified staff was a challenge to rural banks in rendering BAS to customers. Also, twenty-two percent strongly disagreed, while eleven percent agreed that a lack of qualified staff was a limitation to delivering BAS to customers. On the other hand, twenty-two percent disagreed that the lack of qualified staff was a challenge encountered by rural banks in offering BAS. In contrast, eleven percent strongly agreed that the lack of qualified personnel was a challenge rural banks encounter in delivering BAS to customers.

As shown in item $\mathrm{C}$ of Table 12, thirty-three percent agreed that inadequate information in managing customers' businesses was a challenge rural banks face in delivering BAS. Also, twenty- three percent were uncertain if inadequate information in managing customers' businesses was a challenge rural banks encounter in delivering BAS. However, thirty-three percent disagreed that inadequate information in managing customers' businesses was a hindrance to rural banks in offering BAS to customers. In contrast, eleven percent strongly agreed that inadequate information in managing customers' businesses posed as a challenge to rural banks in rendering BAS to their customers.

As shown in item D of Table 12, thirty-three percent agreed that the inability to keep regular contact with customers was a challenge rural banks faced in delivering BAS to customers. In contrast, another thirty-three percent strongly agreed that the inability to keep regular contact with customers was a hindrance to rural banks in delivering BAS to customers. However, twenty-three percent were uncertain if the inability to keep regular contact with customers posed as a challenge to rural banks in offering BAS. Also, eleven percent disagreed that the inability to keep regular contact with customers was a limitation to rendering BAS to customers.

As observed in item $\mathrm{E}$ of Table 12, thirty-four percent agreed that rural banks' inability to develop new business strategies for customers was a challenge faced by rural banks in offering BAS. Twenty-two percent strongly agreed that inability to develop new business strategies was a limitation to rural banks in providing business advisory services to customers. On the other hand, eleven percent disagreed, while another eleven percent strongly disagreed that the inability to develop new business strategies was a challenge to rural banks in delivering BAS. Twenty-two percent were, however, uncertain that the inability to develop new business strategies was a hindrance to rural banks in offering business advisory services to customers. 


\subsection{Discussion of Findings}

\subsection{1: Research objective One: Relationship between Loans and Advances and Rural Development}

The research found that there was a strong but inverse correlation between loans and advances that were given to customers and rural development. This means, while most rural dwellers of the Wenchi municipality are taking more loans from the rural banks, these loans do not help in rural development. This finding can be as a result that most of the customers used the loans acquired from the banks to undertake personal endeavors; however, the loans do not translate into financially empowering the customers for rural development. The finding reflects the findings of Dandekar and Bhattacharya (2017), who stated that most loans given out by rural banks end up burdening rural dwellers with more debts. The findings in this study also reflect the findings of Afful, Hejkrlík, and Doucha (2015) who pointed out that most rural banks give out loans with very similar or higher interest rates as commercial banks, hence making it very difficult to customers, that is rural dwellers, to pay off the loans on time. This results in high default rates among rural dwellers, as asserted by Agyapong (2016). The assessment by Appiah (2016) is in line with the findings from this study in which most of the rural bank staffs indicated that high-interest rate, as well as a high default rate, was a major challenge rural banks encounter in granting loans and advances to customers. The inverse relationship between loans and advances given out by the rural banks and rural development shows the original mandate or goal for the creation of rural banks in Ghana is no longer adhered to.

Findings from the study also showed that a larger number of respondents had ever applied for a loan. The respondents indicated they applied for personal loans, business loans, susu loans, and microfinance loans as well as funeral loans. For the respondents that had never applied for a loan, they specified when inclined to apply for a loan; they would apply for a business loan, microfinance loan, or personal loan. This shows rural dwellers' preference for especially the business loan, microfinance loan, and personal loan.

\subsection{2: Research objective Two: Relationship between Business Advisory Services and Rural Development} In this study, it was established that there was a positive correlation between the status of business advisory services (BAS) and rural development. This is better interpreted with the findings that most customers that are rural dwellers have not taken advantage of any of the BAS offered by the rural banks and the finding in which most customers indicated BAS had not played a role in rural development. This implies that rural development will depend on whether or not customers take advantage of the BAS offered by rural banks. The finding also implies that rural banks can help in rural development by ensuring BAS is offered readily to customers. This means that with better advice on how to manage one's finances, there can be financial growth among rural dwellers who will translate into rural development. The finding is in line with the conclusions of Kochukalam, Thomas, and Joseph (2018), who pointed out that when customers are advised on how to manage their wealth, it helps raise the standard of living of the customers.

\subsection{3: Research objective Three: Challenges Faced by Rural Banks in Rural Development}

The findings of the challenges we're presented with respect to loans and advances given out by the rural banks and the business advisory services rendered by the rural banks. With regards to the challenges relating to granting loans and advances, it was revealed by most of the bank staffs that high-interest rate, high default rate, and lack of collateral security were major hindrances rural banks faced in granting loans and advances to rural dwellers. It can be implied that because most customers usually cannot provide adequate collateral security, rural banks find it difficult to grant loans and advances to these customers.

The need for collateral security/guarantor in loan acquisition helps protect the rural banks in case of default. And because of the high default rate, rural banks also find it difficult to grant loans and advances to these rural dwellers without adequate security. Alhassan (2018) pointed out that although rural banks are required to help rural dwellers in loan acquisition, it also has the responsibility to operate with profitability. This means, it simply cannot grant loans and advances without adequate protection of the bank. Another challenge was the high interest rate attached to loans and advances offered by rural banks. The high-interest rates tend to discourage the rural dwellers from seeking out loans and advances to aid them in their ventures. The rural bank's reluctance to lower interest rates to rates affordable to rural dwellers poses a challenge to the rural bank's efforts to help in rural development.

Also, findings on challenges with respect to business advisory services (BAS) revealed that customers' lack of interest in the business advisory service, lack of qualified staff with expert knowledge in BAS, inadequate information on customers' businesses as well as inability to keep regular contact with customers and inability to develop new business strategies were some challenges the rural banks faced in delivering BAS to their customers. This finding reflects the indication by most respondents (customers) that BAS does not play a role in rural development. This shows that most customers were of the opinion that BAS is a service that is rarely or not at all offered by rural banks. The finding also shows that rural banks are only focused on transactional forms of service, such as deposits, withdrawals, and money transfers. These findings reflect those of Owusu-Antwi, Antwi, and Crabbe (2014), who pointed out that rural banks' operations have shifted form empowering rural communities to seek only services aimed at making a profit at the expense of the rural dwellers. 


\subsection{SUMMARY, CONCLUSION AND RECOMMENDATIONS}

\subsection{Summary}

The purpose of the research work was to examine the relationship between loans and advances and business advisory services of rural banks to rural development. This study employed a descriptive research design. The instrument used for the study was questionnaires. The population size was 10,000 customers and 50 Bank Staff approximately. Stratified sampling and simple random sampling was used to select the sample. A total sample of 203 respondents took part in the study. The data was analyzed into percentages, frequencies, and the use of nonparametric tests to test (Kendall rank correlation coefficient) the relationship between loans and advances and business advisory services.

The main research objectives were:

1. To determine if there is a significant relationship between loans and advances and rural development in Wenchi Municipality.

2. To ascertain if there is a significant relationship between business advisory services and rural development in Wenchi Municipality.

3. To examine the challenges faced by Rural Banks in developing rural communities in the Wenchi Municipality.

The study discovered a number of findings from the analysis of data.

The study found out that there was a strong but inverse relationship between loans and advances that were given to customers and the performance of rural banks in rural development. The findings also showed that respondents who had ever sought a loan indicated they applied for a personal loan, business loan, susu loan, as well as a microfinance loan and funeral loan.

Also, the findings showed that there was a positive correlation between the status of a business advisory service offered (BAS) by rural banks and rural development. From the findings, most of the customers indicated they had not received BAS from the rural banks, while most of the bank staffs indicated the rural banks offered BAS. With regards to the role BAS played in rural development, most of the respondents indicated they were not sure if BAS play a role in rural development.

With respect to the challenges rural banks face regarding loans and advances granted to rural dwellers, most of the bank staff indicated that high-interest rate, high default rate, poor operation of the account and lack of collateral security were major challenges rural banks faced in offering loans and advances to rural dwellers in order to improve on rural development. Findings on challenges with respect to business advisory services (BAS) also revealed that customers' lack of interest in the BAS, lack of qualified staff with expert knowledge in BAS, inadequate information on customers' businesses, inability to keep regular contact with customers as well as inability to develop new business strategies for customers were some challenges rural banks faced in offering BAS to rural dwellers.

\subsection{Conclusions}

A number of conclusions were drawn from the findings of the study. Firstly, it can be concluded that loans and advances that are accessed by rural dwellers do not directly translate into rural development in Wenchi Municipality. In this regard, the relationship between loans and advances sought by rural dwellers and rural development is one that is not directly linked.

The second conclusion is that the state of business advisory services of Rural Banks directly influences rural development in the Wenchi municipality. The results indicate that the relationship between BAS and rural development is one that directly affects one each other.

Lastly, the study concludes that the prominent challenges faced by the rural banks in giving out loans and advances towards rural development include high-interest rate, high default rate, and lack of collateral security. Also, the prominent challenges faced by the rural banks in delivering business advisory services towards rural development include customers' lack of interest in the BAS, lack of qualified staff with expert knowledge in BAS, inadequate information on customers' businesses, inability to keep regular contact with customers as well as inability to develop new business strategies for the customers.

\subsection{Recommendations}

The study found out that there was a strong but inverse relationship between loans and advances that were given to customers and the performance of the rural banks in rural development. It is therefore recommended that credit officers should offer business advisory services to customers on the proper usage of loans and advances granted to them; this will ensure that customers use the loans for the purpose for which the loan facility has been advanced to them in order to improve on rural development.

It was deduced from the findings that there was a positive correlation between the state of business advisory services in rural banks and the performance of rural banks in rural development. It is therefore recommended that rural banks should put much emphasis on developing the facility/office of business advisory services, which will 
help the banks to finance rural enterprises, which intend will transform into rural development.

With respect to the challenges rural banks face regarding loans and advances granted to rural dwellers, it was found out that, high-interest rate, high default rate and lack of collateral security were significant challenges rural banks faced in granting loans and advances to rural dwellers, in that regard, it is recommended that credit officers of rural banks should always do a proper appraisal on customers businesses in order to grant loans to customers who will be able to utilize the money well and repay when the time is due. This will help reduce high default rates associated with loans usually given out to customers. It is also recommended that rural banks should use part of customers' money in their accounts as cash collateral in order to enable customers' access loan facilities from their institutions. Again, even though rural banks are into the business to make a profit, it is recommended that the banks should charge interest rates lower than that of the rates of commercial banks in order to enable rural dwellers to access loans and advances to enable them to improve on their businesses which will transform into rural development.

Also, concerning the challenges rural banks face in delivering business advisory services for rural development, it is recommended that staff of the rural banks should sensitize customers on the need to use the BAS rendered by the bank in order to assist them to manage their businesses effectively and efficiently. Also, the banks should organize workshops to equip staffs with the necessary knowledge to provide BAS to their customers and to train staff on how to develop new business strategies to assist customers' improvement in their business in order to improve on rural development. Again, it is recommended that rural banks should keep regular contact with their customers in order to know the type of BAS, which will help improve their businesses. Also, the rural banks should keep regular contact with their customers, which will help the banks to have adequate information on the customers and their businesses.

\subsection{Suggestions for Further Studies}

The limitations of this study offer opportunities for future research. The study could have looked at rural banks in rural areas in the entire region, but due to time to meet deadlines and also financial difficulties, the study was restricted to a smaller area. So it is recommended that further studies could expand the scope of repeating the study.

\section{References}

Addae-Korankye, A. (2014). Causes and control of loan default/delinquency in microfinance institutions in Ghana. American International Journal of Contemporary Research, 4(12), 36-45.

Adenle, A. A., Azadi, H., \& Manning, L. (2018). The era of sustainable agricultural development in Africa: Understanding the benefits and constraints. Food Reviews International, 34(5), 411-433.

Adrian, T., \& Ashcraft, A. B. (2016). Shadow banking: a review of the literature. In Banking Crises, 282-315. Palgrave Macmillan, London.

Afful, C. F., Hejkrlík, J., \& Doucha, T. (2015). Rural banking in Ghana and its impact on ruralfarmers. Case study of the Birim South District, Ghana. Asian Social Science, 11(25), 101.

Afiriyie, H., \& Akotey, D. O. (2013). Credit risk management and profitability of rural banks in the Bono region of Ghana. European Journal of Business And Management, 5.

Agyapong, R. (2016). Rural banking in Ghana: it impacts on rural farmers (a case study of Adansi rural bank) (Doctoral dissertation).

Akudugu, M. A. (2011). Rural banks' financial capital and livelihoods development of women farmers in Ghana. Journal of Enterprising Communities: People and Places in the Global Economy, 5(4), 248-264.

Alhassan, S. B. (2018). Rural banking and rural development, the case of selected rural banks In the Northern region (Doctoral dissertation)

Appiah, S. K. (2016). Evaluation of credit management and its effect on the performance of rural banks in Ghana: a case study of Adansi rural bank ltd. Fomena-Ashanti (Doctoral dissertation).

Appiah, S. (2016). Contributions of rural banks to small and medium scale enterprises development: a case study of Juaben rural bank ltd (Doctoral dissertation).

Asiedu-Mante, E. (2011). Rural banking in Ghana. Accra: Combert impressions ltd.

Atta Mills, E., \& Amowine, N. (2013). The rural bank profitability nexus: evidence from Ghana. International Journal of Application or Innovation in Engineering and Management, 2(4).

Baidoo, S. T., \& Baidoo, S. T. (2016). Investigating factors that influence an individual's demand for loans in Ghana: a case of Kwahu West municipality (Doctoral dissertation).

Bank of Ghana (2018). Banking Sector Report. Quarterly Economic Bulletin. Accra: Bank of Ghana.

Banson, F. A. K., Sey, E., \& Sakoe, J. (2012). The role of mobile deposit in deposit mobilization in Ghana. Asian Journal Of Business And Management Sciences, 1-18.

Barrett, C. B., Christiaensen, L., Sheahan, M., \& Shimeles, A. (2017). On the structural transformation of rural Africa. The world bank.

Bateman, M., \& Chang, H. J. (2012). Microfinance and the illusion of development: From hubris to nemesis in 
thirty years. World Economic Review, (1).

Bawumia, M. (2015). The role of the central bank in reforming the financial sector: the case of Ghana. Key determinants of national development: historical perspectives and implications for developing economies, 303-333.

Bennett, R. L., Güntay, L., \& Unal, H. (2015). Inside debt, bank default risk, and performance during the crisis. Journal of Financial Intermediation, 24(4), 487-513.

Bhalla, K., Kumar, T., \& Rangaswamy, J. (2018). An integrated rural development model based on comprehensive life-cycle assessment (LCA) of Khadi-Handloom industry in rural India. Procedia CIRP, 69, 493-498.

Bielecki, T. R., \& Rutkowski, M. (2013). Credit risk: Modeling, Valuation, and hedging. Springer science \& business media.

Birchall, J. (2012). A member-owned business approach to the classification of co-operatives and mutuals. The Co-operative Model in Practice, 67.

Boateng, A. A. (2016). The effect of computerization on record-keeping at Offinso rural bank (Doctoral dissertation).

Carley, M., \& Christie, I. (2017). Managing sustainable development. London, U.K, Routledge.

Chambers, R. (2014). Rural development: Putting the last first. London, U.K, Routledge.

Creswell, J. W. (2017). Research design: Qualitative, quantitative, and mixed methods approach. Thousand Oaks, United States. Sage publications.

Dandekar, A., \& Bhattacharya, S. (2017). Lives in debt: Economic \& political weekly, 52(21), 77.

Demirguc-Kunt, A., Klapper, L., Singer, D., Ansar, S., \& Hess, J. (2018). The global index database 2017: Measuring financial inclusion and the fintech revolution. The world bank

Devi, R. U. (2012). Impact of co-operative loan on agriculture sector: A case study of ED district of Andhra Pradesh. Researchers' World, 3(4), 74.

Dickerson, A., \& Popli, G. (2018). The many dimensions of child poverty: Evidence from the UK millennium cohort study. Fiscal Studies, 39(2), 265-298.

Donou-Adonsou, F., \& Sylvester, K. (2016). Financial development and poverty reduction in developing countries New evidence from banks and microfinance institutions. Review of Development Finance, 6(1), 82-90.

Dupas, P., Green, S., Keats, A., \& Robinson, J. (2012). Challenges in banking the rural poor: Evidence from Kenya's western province. National bureau of economic research, 10(17).

Dzadze, P., Aidoo, R., \& Nurah, G. K. (2012). Factors determining access to formal credit in Ghana: A case study of smallholder farmers in the Abura-Asebu Kwamankese district of the central region of Ghana. Journal of Development and Agricultural Economics, 4(14), 416-423.

Edem, D. B. (2017). Liquidity management and performance of deposit money banks in Nigeria (1986-2011): An Investigation. International Journal Of Economics, Finance And Management Sciences, 5(3), 146-161.

Enu-Kwesi, F., Koomson, F., \& Baah-Mintah, R. (2013). The contribution of the Kakum rural bank to poverty reduction in the Komenda-Edina-Eguafo-Abrem municipality in the central region, Ghana. Ekonomski Anali/Economic Annals, 58(197).

Erwin, K., Abubakar, E., \& Muda, I. (2018). The relationship of lending, funding, capital, human resource, asset \& liability management to non-financial sustainability of rural banks (BPRs) in Indonesia. Journal of Applied Economic Sciences, 13(2).

Firth, R., \& Yamey, B. S. (2013). Capital, saving, and credit in peasant societies: a viewpoint from economic anthropology. Routledge, 15-34.

Flora, C. B. (2018). Rural communities: Legacy change. New York. Routledge.

Gatzert, N., Schmit, J. T., \& Kolb, A. (2016). Assessing the risks of insuring reputation risk. Journal of risk and insurance, 83(3), 641-679.

Ghana Statistical Service, (2012). The 2010 population and housing census: Summary report of final results. Accra: Sakoa Press Limited.

Guinjoan, E., Badia, A., \& Tulla, A.F (2016). The new paradigm of rural development. Theoretical reflection and reconceptualization from the rural web. $B A G E,(71)$.

Hanushek, E. A. (2013). Economic growth in developing countries: The role of human capital. Economics of Education Review, 37, 204-212.

Hartman, T. (2015). Development of non-agricultural enterprises in rural areas in the EU. Turku university of applied science, 35 .

Hewson, C., \& Stewart, D. W. (2014). Internet research methods. Wiley Statsref: Statistics Reference Online, 1-6. IFAD (2012). International Fund for Agricultural Development report: The state of food insecurity in the world. FAO, Rome, Italy, 8-11.

Jose, S., \& Chacko, J. (2017). Sustainable development of microfinance customers: An empirical investigation based on India. Journal of Enterprise Information Management, 30(1), 49-64.

Hayford, S. (2012). The Development of small-medium enterprises and their impact on the Ghanaian economy 
(Doctoral dissertation).

Kochukalam, C., Thomas, J., \& Joseph, M. B. (2018). Factors influencing the choice of banks in a millennial customer perspective. Global Journal of Commerce and Management Perspective, 7(1), 1-6.

Koduah-Boateng, J. (2016). The contribution of rural banking in terms of loans assessment to the improvement of the living conditions of the people of Ejisu-Juaben district - A case study of Juaben rural bank ltd (Doctoral dissertation).

Kwapong, S. D. (2013). Application of linear programming to optimal credit portfolio: The case of Akuapem Rural bank ltd (Doctoral dissertation).

Kwarteng, O. (2017). Financing small and medium-size businesses: experiences from Kwaebibirem rural bank limited, Asuom, Ghana (Doctoral Dissertation).

Lavoie, F., Pozzebon, M., \& Gonzalez, L. (2011). Challenges for inclusive finance expansion: The case of Credit Amigo, a Brazilian MFI. Management international/International Management/Gestión International, 15(3), 57-69.

Lin-Hi, N., \& Blumberg, I. (2018). The link between (not) practicing CSR and corporate reputation: Psychological foundations and managerial implications. Journal of Business Ethics, 150(1), 185-198.

Muller, E. (2012). Innovation interactions between knowledge-intensive business services and small and mediumsized enterprises: an analysis in terms of evolution, knowledge, and territories. Springer Science \& Business Media.

Murphy, P. E. (2012). Tourism: A community approach. London, U. K. Routledge.

Nair, A., \& Fissha, A. (2010). Rural banking: The case of rural and community banks in Ghana. World Bank Agriculture and Rural Development Discussion Paper, (48).

Okoye, L. U., Adetiloye, K. A., Erin, O., \& Modebe, N. J. (2016). Financial Inclusion: A panacea for balanced economic development.

Owusu-Antwi, G. (2009). Impact of financial reforms on the banking system in Ghana. International Business \& Economics Research Journal, 8(3), 77-100.

Owusu-Antwi, G., Antwi, J., \& Crabbe, M. (2014). The Performance of rural banks in Ghana: The ages have passed anything recommended for the future. International Review of Management And Business Research, 3(2), 1047.

Owusu-Dankwa, I., \& Gyamfi, P. B. (2013). Principles and practice of lending in the banking sector: a case study of some selected banks in Ghana. Journal of Contemporary Integrative Idea, 1(2), 9-12.

Pattanaik, B. K., Rustagi, P., Menon, R., \& Farooquee, N. A. (2018). Introduction to development and development theories. Ignou Peoples University, 17.

Platteau, J. P. (2015). Institutions, social norms, and economic development. London, U.K, Routledge.

Quartey, P., Danquah, M., \& Iddrisu, A. M. (2017). Rural financial intermediation and poverty reduction: Evidence from Ghana. Project Report Prepared for ORID, University of Ghana, Legon.

Rahman, S., Hussain, A., \& Taqi, M. (2014). Impact of agricultural credit on agricultural productivity in Pakistan: An empirical analysis. International journal of advanced research in management and social sciences, 3(4), 125-139.

Ravallion, M. (2017). Poverty comparisons. London, U.K, Routledge.

Reddy, D. M., \& Prasad, K. V. N. (2011). Evaluating the performance of regional rural banks: an application of the CAMEL model. Researchers World, 2(4), 61.

Rodrik, D. (2016). An African growth miracle? Journal of African economies, 27(1), 10-27.

Sacerdoti, E. (2005). Access to bank credit in sub-Saharan Africa: key issues and reform strategies. International monetary fund.

Singh, G., Sindhwani, B. K. S. K. S., \& Banerjee, M. M. (2018). A Study of the role of government and financial institutions in rural market development in India. Indian Rural Market: Opportunity and Challenges in The Global Context, 1(1), 336-339.

Tetteh, E. K., \& Antwi, K. B. (2013). Expanding rural economies through microfinance: Chronicling the experience of microcredit clients of the upper Manya Krobo rural bank of the eastern region of Ghana. Journal of Economics and, 67-79.

Thakor, A. V. (2015). The financial crisis of 2007-2009: why did it happen, and what did we learn?. The review of corporate finance studies, 4(2), 155-205.

Vaznoniene, G. (2015). The role of rural community-enhancing rural social infrastructure changes. In research for rural development. International scientific conference proceedings (Latvia). Latvia University of agriculture. 